„Bohemistyka” 2021, nr 3, ISSN 1642-9893

Marie ČECHOVÁ

DOI: 10.14746/bo.2021.3.6

Západočeská univerzita

\section{Kam spěje vývoj nejen flexe proprií?}

Keywords: proper names, common names, inflection, declination, derivation, uninflectedness, tendency after invariability of stem

Klíčová slova: propria, apelativa, flexe, skloňování, odvozování, neohebnost, tendence po neměnnosti kmene

\section{Abstract}

The paper will focus on formal morphology in the broader sense, i.e. on the derivation of proper names, not only on their inflection, even with regard to trends in common names.

Systemic forms of proper names and new forms used in current communication, conformity and differences between common and proper names will be compared. The question is to what extent contemporary Czech retains inflection as an essential feature of inflective language and whether it retains inflection of proper names, or to what extent.

Př́íspěvek se zaměří na formální morfologii v širším slova smyslu, tedy i na odvozování proprií, nejen na jejich skloňování, a to i se zřetelem k tendencím u apelativ. Budou se porovnávat propriální podoby systémové a novotvary užívané $\mathrm{v}$ současné komunikaci, shody a diference mezi apelativy a proprii. Klade se otázka, do jaké míry si současná čeština drží ohýbání jako podstatný rys flexivního jazyka a zda si udrží ohebnost u propriálních pojmenování, event. do jaké míry.

Na dané téma se $\mathrm{v}$ předloženém příspěvku chci podívat $\mathrm{z}$ pozice kultury řeči, nejsouc onomastik, omlouvám se odborníkům, že jim „lezu do zelí”, hledajíc jisté tendence, jejichž zjištění by mohlo být prospěšné nejen pro výuku, ale snad vůbec pro veřejnost. Soustředíme se na několik vybraných problémů:

1. začleňování proprií do morfologického systému češtiny;

2. dvojtvary podle čísla a rodu i pádů v různých příručkách;

3. tvarosloví u víceslovných toponym;
4. změny v pojmenováních zahraničních, u exonym;

5. zběžně i ohýbání u zkratek chrématonym;

6. začleníme odbočku, ovšem pro uživatele významnou, totiž pravopisnou (některých typů vlastních názvů);

7. postihneme tendenci v ohebnosti osobních jmen.

Ad 1. Soustredíme se na $\mathrm{z}$ a č le ňo vání a ne za č le ň o vání propriído morfologického systému češtiny v širším s lova s mys lu, na shody a odlišnosti u apelativ a proprií v daném okruhu problémů. Sledujeme, do jaké míry si současná čeština drží ohýbání jako podstatný rys flexivního jazyka, a uvažovat o tom, do jaké míry si udrží ohebnost u propriálních pojmenování, eventuálně vůbec. Vycházíme z přesvědčení, že ani u proprií nejde o jednotky neorganizované, stojící mimo systém, třebaže i u nich nepochybně dochází k rozvolňování systému pod vlivem rozvolněné komunikační praxe.

Řada př́íruček češtiny si všímala a všímá si vlastních jmen a jejich tvarů podle jejich gramatických kategorií. Namátkou jmenujme uživatelské příručky z posledních desetiletí 20 . století: kolektivní práce Čeština všední a nevšední (1972), Čeština za školou (1979), z přelomu století pak např. Český jazyk na prelomu století (1997), Akademická přiručka českého jazyka (2014, dále APČJ) aj., i individuální díla monografická (jako Polívková 1985) i texty časopisecké (např. Polívková 1985; Svobodová 2017/2018; Jílková 2018, 2019; Šimandl 2000), či sborníkové (např. Šrámek 1999, Pastyř́ík 2009, Štěpán 2019) $)^{1}$

${ }^{1}$ Jmenovaná Akademická př́ručka patří rovněž mezi př́ručky uživatelské, dokonce s doložkou Ministerstvem školství, mládeže a tělovýchovy, tedy jde o př́ručku kodifikační, a to i přes některé odlišnosti této příručky od kodifikačních př́ruček dalších, Pravidel českého pravopisu a Slovníku spisovné češtiny. Prezentuje se však jako 'akademická', asi proto, že ji zpracovali členové akademického pracoviště, Ústavu pro jazyk český a vydalo ji s podporou Akademie věd nakladatelství Academia. Všimneme-li si spolu se Slovníkem spisovného jazyka českého dvou významů slova akademický 'vysokoškolský" a zvláště pak jeho významu "učený" (dalši významy nás nezajímají) v porovnání s určením příručky, najdeme podstatný rozdíl 
Ad 2. V uvedených i dalších príručkách, v novějších pak více, se objevují dvojtvary tam, kde před desetiletími nebyly zachycovány, $\mathrm{v}$ těchto př́padech se připouštějí dvojtvary, nikoli naopak mizení dvojtvarů. Dvojtvary se týkají kategorií čísla a kategorie rodu (a). Nacházíme však dvojtvary i pádové (b).

Ad a) Lze konstatovat, že jména na -ice inklinují k pluraliím tantum, takže nověji přibývá plurálových tvarů tam, kde bývaly kodifikovány jen tvary singulárové, srov. plurálové podoby i u původních singularií tantum typu Prčice, Hostivice. Avšak jen u osob neznalých místních poměrů se tak dvojtvary (dokonce v prŕručkách) objevují např. v př́ipadech jako: do Roudnic, do Votice. S. Utěšený píše:

[...] tolerování tvarů množného čísla u jmen typu Roudnice je právě jen východiskem z nouze (Utěšený 1987, s. 118).

V místním úzu se užívá jen ty Votice, nikoli ta Votice. Přitom v dativu a lokálu těchto pluralií na Benešovsku běžně fungují dvojtvary podle vzoru i mužského i ženského Voticưm, Voticím, Popovicům, Popovicím, Postupicưm, Postupicím ..., ale nikoli v instrumentále, tam jen zakončení ženské -emi. Pravděpodobně to platí nejen pro Benešovsko, ale i velkou část Čech. L. Jílková za obvyklou pokládá v dativu koncovku -im, někdy připouští -ům (Jílková 2019, s. 95). Už starší mluvnice, např. Česká mluvnice (dále ČM) z r. 1960 u pluralií tantum, kodifikovaly rodové dvojtvary především v dativu Budějovicím i Budějovicuim, Beskydám i Beskydům a v lokále Beskydách i Beskydech, v tomto př́padě i instrumentálem s Beskydami is Besky$d y$ (žr., С̌M, s. 141).

Jména se zadopatrovou, respektive hrtanovou souhláskou pak kolísají ve tvaru lokálu mezi měkčením a neměkčením souhlásky Stachách, Staších, Břehách, Březích (řidč. -zích... Polívková 1985, s. 76).

mezi významem slova akademický a určením př́ručky: „Je zamýšlena jako pomůcka pro všechny uživatele češtiny, kteří se chtějí či potřebují poučit” (s. 37). Procházíme-li publikacemi, neujde nám, že odrážejí nejistotu uživatelů ve volbě tvarů proprií. Toho si budeme všímat.
Na postupu je neměkčení, a to $\mathrm{v}$ souladu s tendencí po neměnnosti kmene $u$ apelativ. Ze styku se stachovskými rodáky lze konstatovat, že jen mluvčí usilující o vybraný způsob řeči volívají tvar se zakončením -ích. Viz i mnou použité adjektivum stachovský, které není kodifikováno, i když v místním úzu je zcela běžné. (Polívková i Internetová jazyková př́ručka mají jen stašský.)

Výše jsme si povšimli pohybu i v mluvnickém rodě, některá toponyma mají dvojí rod a pak dvojtvary v nepřímých pádech. APČJ udává rodové varianty, ženské a mužské, samozřejmě nejen v nominativu, ale i v instrumentálu: Aší, Ašem, Pankrácí, Pankrácem. Ověřila jsem namátkou v lednu 2000 u regionálních mluvčích, že vesměs volí tvary femininní ta $A \check{s}, s$ Aši . Stejnou zkušenost má i onomastik P. Štěpán:

Ano, to mohu potvrdit z vlastní zkušenosti, v místním úzu je jen ta Aš, setkal jsem se nejednou i s tím, že místní obyvatelé na podobu ten $A \check{s}, s$ Ašem reagovali negativně a považovali ji za chybnou (osobní sdělení).

U jmen, v nichž je místní úzus jednotný, pevně zakotvený, měla by být jednota respektována i v př́ručkách. Např. u jména Vlašim místní neužívají v genitivu tvar na -ě (Vlašimé), ale tvar na -i (Vlašimi), avšak APČJ připouští -ě. U jména Želiv jsem v řeči místních a v regionálním úzu zaznamenala jen rod mužský (do Želiva, $s$ Želivem, nikoli i ženský; *Želivi, Želivi), A. Polívková však konstatuje kolísání v rodě a uvádí v genitivu dvojtvary Želiv i Želivi, v lokále -ě i -i (Polívková 1985, s. 184), ani u Př́ibramanů jsem nezaslechla genitiv Př́bramé, ale APČJ má kolísání Přibrami/Př́bramě, stejně tak i J. M. Tušková (2016). K tomu P. Štěpán doplnil:

Je sice dnes už výrazně méně častá, ale u nejstarší generace Příbramanů se dosud vyskytuje, např. můj 95letý děda ji běžně uživá. Pokud by z kodifikace zmizela, oficiální názvy několika obcí (Lhota u Př́ibramě, Buková u Příbramě, Vysoká u Př́íbramě) by se dostaly do rozporu s jazykovou kodifikací; přejmenování obcí by se prosazovalo obtížně (osobní sdělení).

Ad b) Nepochybná je motivace vzniku proprií na pozadí existujících apelativ. O fundující úloze apelativ píše R. Šrámek in Propria 
v systému mluvnickém a slovotvorném (Šrámek 1999, viz i Tušková 2016) včetně jejich ovlivňování tvarů proprií. Jindy jde o pouhou analogii podle jiných proprií (blíže viz P. Štěpán 2019).

V lokále, a to shodně $\mathrm{s}$ tvarem $\mathrm{v}$ genitivu u obecných jmen cizího původu se prosazuje koncovka $-u$ (o tom už před mnoha lety psala Čechová), typ manifest, $-u$, dekret,- $u$, aby nedocházelo ke změně kmenové souhlásky, obdobně je to i u proprií, tedy $v$ Bruselu, nikoli Brusele, podobně $v$ Kosovu, zvláště pak u slov se zadopatrovou hláskou v zakončení, je jen: v Hamburku, Insbrucku, v Lutychu, Krivom Rogu... U místních jmen zakončených na $-m$ sledujeme sklon k tvarům ženským, viz Toužim, $s$ Toužimí, takže by snad mělo být Rotterdam, Rotterdami, v Rotterdami, s Rotterdamí?, ale SSJČ má pochopitelně jen muž. rod, v genitivu koncovku $-u$, tvary ženského rodu jsou $\mathrm{v}$ češtině zcela neuzuální.

Doložme tendenci k neměnnosti kmene, která je zřetelná nejen u jmen cizího původu, ale i u vlastních jmen českých či počeštěných I A. Polívková (1985) má jen: v Člunku, v Doubravníku, v Habrku (Habrek), Kruhu, Kunžaku, Lezníku, Mnišku, Nejdku, Oseku, Osíku, Ostředku, Prysku, Srchu, Úštěku, Vroutku, ale má Kružberku i -ce, Mělníku i -ce, Točníku i -ce, Vimperku i -ce, Zábřeze, -u (viz pořadí koncovek), Zbirohu, -ze, Žamberku, -ce (nemá *Člunce, *Srše, *Habrce apod.). Žretelně převažují podoby beze změny kmenové souhlásky. Pokud jsou varianty na -e uváděny, pak na druhém místě, až na Zábřeh, tj. tvar starší a regionálně petrifikovaný. Ovšem není zřetelné, proč právě jen u uvedených jmen jsou dvojtvary, kdežto u některých jiných, u nichž by nenastaly problémy se záměnou s apelativy, tomu tak není. Souhlasím s P. Štěpánem:

Možná je to částečně dáno tím, že varianty na -e se v řadě př́ípadů nevyskytují ani v místním úzu, např. *Nejdce, *Ostředce, *Srše, *Vroutce, *Prysce. Část těchto obcí leží v oblasti (do roku 1945 převážně německých) Sudet, kde lze absenci podob na -e poměrně snadno vysvětlit (osobní sdělení).

Všimněme si všeobecně známého a běžného jména Korea (které se skloňuje podle vzoru žena nebo růže Korey/Koreje), rozhlasoví moderátoři, tedy profesionálové, běžně oznamují: do Koreji, kolem Kore- $j i$, tedy volí v genitivu tvar totožný s tvarem dativu, v němž je tvar Koreji náležitý (podle vzoru růže). Pravděpodobně tady hraje roli souběh samohlásek -ey mezi něž se vkládá $j$, takže zní [eji].

Za zmínku stojí, že slovanská jména s pohyblivou samohláskou, která se v nepřímých pádech vypouštěla, si v současnosti pohyblivou samohlásku ponechávají (jistě pro menší vzdělanost uživatelů v oblasti klasického vzdělání), třebaže se to neshoduje s výchozím jazykem: Zadar, v genitivu původně jen Zadru, v současnosti zcela převážně Zadaru, tak je tomu i u jmen jihoslovanských na -ac jako Karlovac, Kragujevac apod., ale také některá slovenská jména se tak chovají, např. název Ružomberok bývá v češtině často skloňován $v$ Ružomberoku místo Ružomberku. Obdobně u řecko-latinských jmen se v nepřímých pádech vypouštěly př́ipony -os, -um..., v současnosti se leckdy běžně nevypouštějí, takže slyšíme nejen u obecných označení kosmosu, globusu, datumu (tento tvar dokonce toleruje APČJ, s. 303), ale leckdy i u vlastních jmen, např. Rhodosu místo Rhodu, s Herodesem, ba i Zeusem. Zajímavé je, že neslýcháme s Archimedesem, snad vlivem častého používání termínu Archimedův zákon. Zdá se, že dříve běžné odlišování psaní proprií a apelativ poněkud ustupuje; naopak K. Smejkalová (2019) mluví o výrazném převažování tendence k odlišování.

Ad 3. Zajímavý je stav i v tvarosloví u víceslovných místních názv ů:

Ve spojeních typu město Luhačovice už starší mluvnice uváděly dvojí možnosti. Bud' ohýbaly obě součásti názvu s městem Luhačovicemi nebo druhé jméno ponechávaly v nominativu: s městem Luhačovice. Stav označovala jako kolísání mezi oběma možnostmi už Česká mluvnice (bez hodnocení; Jedlička, Havránek 1960, s. 108, napřr. v okrese Přibram, do kina Svoboda). Předtím užití nominativu jmenovacího bylo hodnoceno jako nesprávné, r. 1949 předpověděl F. Daně̌ jeho šíření (viz J. Šimandl 2000). Avšak V. Šmilauer (1966, s. 181-182) u názvů řek uznává jen sklonné podoby (na řece Vltavě), ty podle ČNK i dnes převažují. 
Myslím, že dnes se nesklonné podoby, nominativ jmenovací, a sklonné vcelku bez záměru střídají; na ČT 1 moderátor Klepetko: Po vichřici Sabině, kdežto v titulcích souběžně: Po vichřici Sabina, více př́kladů jsme přitom nalézali ve spisovné mediální komunikaci s nominativem jmenovacím: na rozhlasové stanici Vltava, méně často na rozhlasové stanici Vltavě, na stanici Vyšehrad vystupujte vpravo ve směru jízdy spíše než na Vyšehradě, jistě i z možné záměny stanice s pražskou čtvrtí. Nárůst nominativu jmenovacího už před 20 lety postř̌ehl J. Šimandl (i se zdůvodněním). Nominativ jmenovací má výhodu, že nenechává př́ijemce na pochybách o podobě základního tvaru pojmenování. I. Svobodová vysledovala u dlouhých (tříslovných bezpředložkových) místních názvů (2017/18) převahu nominativu jmenovacího, u dvojslovných kolísání s tím, že u skloňovaných zůstává často v lokále nesklonná podoba. V běžné řeči, situačně jasně orientované, obecné jméno nebývá, v metru slyšíme: vystupte na Muzeu, na Vyšehradě, na magnetoterapii jděte do Goethe (místo do léčebného domu Goethe, nominativ jmenovací, nebo do Goethova/ /Goetheho domu). Jak vidíme, v běžné řeči se užívají pojmenování bez opěrného obecného jména; vlastní jméno někdy zůstává v nominativu, vlastně nezačleněno do věty. Odtud se tyto podoby dostávají do médií (soustavněji jsme sledovali veřejnoprávní stanice českého rozhlasu), viz typ: Byl jsem v Michigan [mičigen] $v$ jedné škole; přednášky, které se konaly na Fakulta stavebni ČVUT Praze; Zlín Film Festival, viz o tom i u Evy Minářové a Jany M. Tuškové (2015), konkurencí nominativu jmenovacího a lokálu se zabývala mj. i Ivana Kolářová (1999). Neohýbaných podob se často užívá především u víceslovných názvů cizích: zaštítěného Instituto Cervantes a Delegation of the European Union to India, nepochybně i z důvodů tvarové bezradnosti mluvčího. A to nemáme na mysli segmentované nepřipravené projevy, v nichž mluvčí rezignuje na flexi, typ No byli jsme. Itálie, Španélsko (viz Hoffmannová, Zeman 2017, s. 55).

Ad 4. Můžeme si všimnout $i$ pohybu v pojmenovávání $\mathrm{m}$ ě s t v z a hra n i čí. Dřívější zvyklost počešt'ovat je ustupuje tendenci ponechávat označení v původní podobě, užívané na území, na němž město leží. Týká se to i jmen dávno počeštěných, exonym typu Řezno < Regensburg, Štýrský Hradec < Graz, Cáchy < Aachen, Benátky < Venezia..., tj. zvláště u těch, jejichž počeštěná podoba se velice vzdálila od podoby původní, ale tato problematika (tzv. exonym) sem nezapadá, takže ji opouštíme, ale zasloužila by si samostatné pojednání.

Pro zajímavost připojme, že (až na výjimky) vlastní zeměpisná jména neskloňují Češi z chorvatského Daruvarska. V knize Češi ve světě 4, Chorvatsko (rozhovory s nimi zapisovala B. P. Šolcová, Dům zahraniční spolupráce, 2018) jsme našli dokladů na neobměňované podoby těchto jmen desítky, skloňované podoby byly zcela výjimečné. Důvodem je asi obtížnost při tvoření tvarů v nepřímých pádech.

Exkurs: Tento důvod je nepochybný u tvarů v nepřímých pádech složených číslovek. Např. od chorvatských Čechů jsme slyšeli/četli u číslovkových výrazů (včetně nesložených) vesměs neohebné podoby: do deset tisíc. $\mathrm{S}$ jejich nesklonností nebo s jejich chybným skloňováním v řečové praxi i odborné a mediální se setkáváme ale i v našem rozhlase a v televizi. I od moderátorů nebo od přizvaných odborníků slyšíme rovněž: do deset tisic, po několika desitek let, bez proudu je asi kolem pět set domácností (viz u moderátorky ČT i redundanci asi, kolem), ministryně ř́ká (ve zprávách na ČT1): jsme na devět seti... nebo jméno po číslovce někteří neskloňují: před šesti let, opakovaně se objevují tvary složeniny desettisicové požáry, poslanec napřr rríká: kvůli osmi set milionům. Zcela běžně jsme nalézali tyto odchylky tedy nejen v mluvě cizinců či u Čechů žijících po generace v zahraničí.

Ad 5. Kolísání zaznamenáváme i u o hýbání zkra te k c h r é m a t o n y m (názvů lidských výtvorů, zahrnujících i názvy institucí) včetně iniciálových, i ty se vyskytují v několika podobách, neskloňované, eventuálně skloňované, ale i s různou obměnou velkých a malých písmen, typy: $s$ UNESCO, bez ČEZu, v Ikee. Jisté tendence u nich zachytil O. Dufek v „Naší řeči” (2016, s. 256-268) se závěrem, že zkratky náležející k vzorům hrad a město většinou zůstávají nesklonné, zkratky patřící k vzoru žena jsou nekonzistentní (UEFA v 95\% nesklonná x ABBA pouze v 5,7\%). Domníváme se, že není účelné jeden $\mathrm{z}$ tvarů př́isně kodifikovat, avšak pravopis by bylo možno sjednocovat (nebot' to je věc čistě konvenční), aby stav, kdy jeden název má několik podob, nebyl běžným jevem. Srov. podoby WI-FI, 
WIFI, vi-fi, vifi. U tohoto označení K. Dvořáková došla k počtu 11 podob (Dvořáková 2015, s. 216-220). I když poněkud odbočíme od pravopisu, podotkněme, že L. Jílková napočítala u výslovnosti apelativa smoothie 14 podob (Jílková 2018, s. 113), ani to není žádoucí, ačkoli ve výslovnosti tohoto slova šlo o odlišnosti drobné.

Ad 6. Na tomto místě si dovolím p rav op is n o u o d b o č ku: Měli bychom si ujasnit, že nemá smysl přeceňovat význam kodifikace u vlastních názvů. Ústav pro jazyk český stále a opakovaně řeší problém psaní velkých písmen (viz řadu grantů a publikací), avšak zhruba po 50-60 letech sledování změn lze konstatovat, že žádná komise problém beze zbytku nevyřešila a nevyřeší, $s$ vyřešením jednoho problému se vynoří další, takže se problém jen posune jinam. Osobní zkušenost mám z komise z 80. let, v níž Z. Hlavsa s podkomisí posunul (a prosadil) psaní velkých písmen u víceslovných názvů typu $\mathrm{Na}$ př́kopě, Na slupi x Na Pořičí.. k nerozlišování obecných a vlastních jmen uvnitř takovéhoto názvu $\mathrm{k}$ jednotnému zapisování plnový znamového slova velkým písmenem: Na Přikopě, Na Slupi, Na Pořičí...

Také dnes je praxe i vlivem této změny rozkolísaná, např. onomastika využila výjimky dané akademickými Pravidly českého pravopisu (1993, s. 42), nepřijala výše uvedenou zásadu a užívá v odborných pracích u podob po předložce malé písmeno, je-li základem pojmenování jméno obecné $\mathrm{Na}$ dlouhých, $\mathrm{Na}$ jitrách, U modřínu atd. (viz Olivová-Nezbedová a kol. 1995). Je třeba si uvědomit, že vedle jazykové kodifikace existuje i standardizace geog ra fi c ké h o ná z v o s loví, která je na rozdíl od jazykové kodifikace v oficiální komunikaci pro určité instituce závazná (viz blíže Štěpán 2020).

Jak vypadá stav v běžné praxi? V jedné středočeské vesnici u místních uživatelů můžeme nalézt $\mathrm{v}$ zapisování názvu hostince (na neoficiálních pozvánkách nebo vzkazech): hostinec Pod Hrází, Hostinec Pod Hrází, Hostinec pod hrází, hostinec Pod hrází, Hostinec pod Hrází, hostinec pod hrází. Tedy jen zdánlivě se problém vyřešil.

Zřetelné je pouze posílení tendence po psaní velkých písmen, např. u názvů institucí se problém jen posunul o ,patro” níže: Velká pís- mena se psávala pouze u názvů nadřazených institucí: Univers/zita Karlova, ale filos/zofická fakulta UK, pedagogická fakulta UJEP... Po změně pravidel r. 1993 se velké písmeno posunulo i k dílčí složce, tj. na název fakult; nyní již velké písmeno nacházíme v naprosté většině u názvů podřízených složek, tj. kateder, fakultních ústavů..., obdobně je tomu u názvů odborů či oddělení různých institucí.

Lze shrnout, že nelze přeceňovat pravomoc ani význam kodifikace vůbec, zvláště ne pak v propriální sféře, ale také ji nepodceňovat, protože může mít a mívá význam rozlišovací, diferencující, pro institucionální komunikaci význam kardinální, rozhodující, zda nap̌r. má x nemá smlouva aj. dokument právni platnost. Přebujelá tendence po velkých písmenech vlivem pravopisu anglického, event. německého (viz Česko Německou hranici např. v prospektu města Aše) by měla být korigována, v komunikační praxi i školou. Škola by neměla přeceňovat pravopis velkých písmen v názvech institucí, protože mnohdy závisí na znalosti reálií. Neměla by stavět diktáty na názvech pro žáky odtažitých institucí, ale soustředit se na pojmenování běžných, zvláště státně a regionálně významných objektů.

Ad 7. Konstatovali jsme tendenci $\mathrm{k}$ nesklonnosti především u místních názvů víceslovných a u jmen institucí. Jisté o me z e ní flexe pozorujeme však i u osobních, a to u rodných jmen i př́ijmení. U jména Otto se to projevovalo už podstatně dř́ve (viz dále), ale i jinde, zvláště u dalších jmen cizího původu, např. Paul [pól] Celanovi (zachyceno na prestižní rozhlasové stanici Vltava, např. 6. 1. 2020). APČJ konstatuje, že ve spojení obecného a vlastního jména osob se nominativu jmenovacího neužívá: se správcem Fridrichem nikoli *se správcem Fridrich, totéž rozhodně konstatuje i I. Svobodová (2017/2018), avšak připouští ho u cizích jmen obtížně skloňovatelných (od malíre Delacroixe i Delacroix).

Ve vojenských dokumentech se praktikovalo už v minulém století neohýbání vlastních jmen osobních $\mathrm{v}$ textu se zdůvodněním, aby se předešlo omylům, event. záměnám osob, takže se v nich psalo $s$ podplukovnikem Oto Poche, eventuálně se v textu jméno ohýbalo, tedy $s$ Pochem, a jeho podoba $\mathrm{v}$ nominativu byla uvedena $\mathrm{v}$ závorce, což 
byl a je jistě prŕístup přijatelnější. Všimněme si např. podoby instrumentálu s panem Chýlem, ta se může vztahovat nejen k jménu Chýla, Chýle ale i k předpokládaným nominativům *Chýl, *Chýlo (i když př́jmení Chýl ani Chýlo jsme nezaevidovali), pouze jméno s nominativem na - a Chýla se od nich odlišuje (Chýlou), obdobně podoba $s$ Otou se vztahuje jak k nominativu Ota, tak i Oto, ten by měl mít pravidelný tvar v instrumentále $s$ Otem, ale jak podotýká APČJ: ,tento způsob se v praxi neužívá" (s. 329). Stejně tak se často neskloňují další rodná jména na -o: s Kvido Hodurou, s Hugo Haasem, s Pablo Nerudou.

Uživatelské potíže představují ne pře chýlená ženská j mé$\mathrm{n}$ a. Kdysi se nepřechylovala pouze jména slavných osobností, u nichž v řečové praxi nedocházelo k omylům, jako Sofia Loren, Maria Calas, ale i u nich byly vcelku běžné podoby přechýlené: Lorenová, Calasová. Problémy nastávaly už dř́ve např. v odborné komunikaci u jmen lingvistek-cizinek, jako Guchmann, Neščimenko. Na tomto místě připomenu zkušenost $\mathrm{z}$ fakultního učitelského semináře, kde referentkačeštinářka představovala dílo pana Neščimenka. Dnes je bohužel rodová záměna běžná (viz Čechová 2017b, s. 22).

V souvislosti s nepřechylováním se nabízí otázka, zda máme užívat u typu pani Svoboda v nepř́mých pádech nesklonné podoby $k$ paní Svoboda, nebo sklonné k paní Svobodě / k paní Svobodovi - ani jedna eventualita neodpovídá českému systému ženských př́ijmení; či snad v nepř́mých pádech přechylovat $k$ pani Svobodové? Nevím zda by se to dotyčné osobě líbilo. P. Štěpán mou domněnku oslabuje konstatováním:

[...] znám ženy s nepřechýleným př́ijmením, které se samy např. do telefonu představují přechýlenou podobou (osobní sdělení).

Já mám zkušenost opačnou, pracovnice finančního úřadu se vždy představuje nepřechýleným jménem. Máme my, uživatelé, kteří přicházíme s těmito př́jmeními do kontaktu, povinnost nepřechylovat, nepřeje-li si to pojmenovávaná osoba, dokonce ani neskloňovat tato př́ijmení? A cožpak dvojčlenná ženská př́ijmení typu Starý Kořánová,
Churavý Bejčková? Nevím, zda by nositelky takových prřijmení přijaly podobu Stará Kořánová, Churavá Bejčková, v případě nepřímých pádů pak podoby ke Staré Kořánové, se Starou Kořánovou, s Churavou Bejčkovou. Neshodné tvary i v tomto případě začínají být zcela běžné. Kdyby nositelky těchto př́ijmení zvolily obě části svého př́ijmení nepřechýlené, šlo by o paní Starý Kořán, pani Churavý Bejček. V zájmu rovnosti pohlaví by pak jejich mužové mohli naopak nabýt př́ijmení *Starý Kořán, *Churavý Bejček nebo snad by mohli mít jméno shodné se jménem manželky (*Starý Kořánová, *Churavý Bejčková) nebo s opačným pořadím? Chápu poznámku P. Štěpána:

Není podle mě vhodné uvádět eventuality, které nejsou možné, tj. neodpovídaj platnému zákonu (osobní sdělení).

Domnívám se však, že snad je na místě i ,trocha” absurdity, vždyt' i podle legislativy dnes možné podoby př́ijmení se mohly zdát před časem absurdní. Dříve byly podoby osobních jmen typu pan Vilém Prokop Mlejnek pokládány za raritní, dnes může docházet a už dochází ke kombinacím směšným až hanlivým, připomínajícím humorné větné seznamy žáků: Malý Zajic Vyskočil Velký Bobek Vytlačil (viz i Čechová, Oliva 1993). Přitom nositelky podobných kombinací si tyto typy jmen volí samy. Nikdo nerozhoduje za ně, na rozdíl od novorozenců, jimž rodné jméno vybírají rodiče.

Značný problém nastává u osobních jmen i s uživáním spojovníku, i když se mnohému uživateli může zdát malicherný. Ten je mnohdy zaměňován s pomlčkou (o tom viz Čechová 2017a, s. 110-111): Pomlčka (dlouhá vodorovná čárka) by neměla být se spojovníkem/tiré/divisem (krátkou vodorovnou čárkou bez mezer) zaměňována. Ten je prostředkem slovotvorným (nikoli syntaktickým ani signálem zastupujícím signál fonetický), oddělujícím dva komponenty složenin, a to slučovacích (žluto-zelené pruhy na tričku, tj. žluté a zelené $\times$ žlutozelený svetr, tj. svetr má barvu zelenou s žlutým odstínem). Mezi dvojčlenným př́jimením býval závazný spojovník bez mezer: Marie Curie-Skłodowská, František Jilek-Oberpfalcer, dnes tato jasná signalizace mizí, užívá se (podle zákona) obou jmen pouze přiřazených 
vedle sebe: Lucie Saicová Řimalová, Radoslava Kvapilová Brabcová, Eliška Skopcová Vychytalová (druhé jméno je prřijmení původní nebo předchozí, např. za svobodna nebo po minulém manželovi). Může tak docházet $\mathrm{k}$ nemilým omylům, čtenář si může myslet, že pisatel zapomněl na interpunkční znaménko, a pokládá jedno označení za pojmenování dvou osob.

Bylo by žádoucí zabránit i tomu, aby nedocházelo ani k opačným mýlkám, $\mathrm{k}$ záměnám dvou osob za jednu, jak se stalo na jednom mezinárodním jednání, na němž byl vyzván k referování Walter Mokijenko. Tehdy šlo o dva spoluautory (Harry Walter a Valerij Mokijenko); nedorozumění vzniklo ze zápisu př́ijmení Walter-Mokijenko), roli v tomto případě sehrál pravděpodobně i fakt, že Walter je nejen př́ijmení, ale i běžné rodné jméno, třebaže ne ukrajinské. Podle našeho názoru bychom jména spoluautorů měli označovat pomlčkou oddělenou z obou stran mezerami, nikoli rozdělovat je jen spojovníkem bez mezer, a tak graficky odlišovat Havránek, Jedlička Česká mluvnice, Jelínek, Styblík Čtení o českém jazyku $\times$ Jílek-Oberpfalcer, avšak Akademická př́ručka českého jazyka v těchto případech pomlčku mezerami neodděluje (Akademická... 2017, s. 135), takže rozdíl od spojovníku není zřetelný. Proto by bylo žádoucí vrátit se k stavu, kdy byla situace a vztahy jasné, i když přijímáme připomínku P. Štěpána:

At' to bude kodifikováno jakkoli, stejně to hodně pisatelů bude psát špatně (už jen proto, že na klávesnici lze napsat jednoduše spojovník, ale pomlčku často ne) (osobní sdělení). ${ }^{2}$

${ }^{2}$ Ke spojovníku se kdysi uchylovali pisatelé i při ohýbání jména. Tak např v knize Jaroslava Medka Co nám tatínek vypravoval z roku 1929 čteme: „Reprodukce dřevorytů A. Levýho z díla »Čechy« se svolením nakladatelství J. Otto...”, aby byla zachována podoba nominativu. Pavel Štěpán mi k tomuto př́íkladu dodal další, v tomto př́padě bez spojovníku: „V Havlíčkově Borové je ulice Zelenýho (podle místního rodáka Václava Zeleného). Užití tohoto tvaru zřejmě souvisí se snahou zachovat $\mathrm{v}$ názvu ulice celou podobu nominativu a až $\mathrm{k}$ ní připojit koncovku".

\section{Dodatek}

Pohyb zaznamenáváme i v tvarech posesivních adjektiv. Nenoremní tvary jsme zachycovali např. u tvaru dativu nejen u apelativ, ale i u proprií: $k$ matčině prítelovi, $k$ Alenině kolegovi. Jindy se místo jmenných tvarů setkáváme s adjektivními tvary složenými: $V$ Karlové ulici, na Jungmannovém náměstí, na Janáčkovej akademii, má (= absolvoval) Jedličkovej ústav (tj. obecněčeský tvar podle vzoru dobrý). V těchto př́padech uživatelé místo posesivních adjektiv volí adjektiva tvrdá. Téměř legendárním se stalo skloňování Miroslava Štěpána na schůzích FF UK v 80. letech, který skloňoval do Univerzity Karlové, k Univerzitě Karlové, o Univerzitě Karlové, ale zaslechneme je i dnes u jiných osob, např. v rozhovoru se známým hercem v programu TV čteme: studoval jsem na Janáčkové akademii múzických umění, u místního názvu moderátor na ČR+ ve zprávách o nehodách hlásí: u Heřmanového Městce, při opakování pak náležitě užije podoby Heřmanova. Už dlouho a frekventovaně se setkáváme s užíváním genitivu posesivního místo posesivního adjektiva (rukopis Havlička), ale o tom se psalo už mnohokrát. My se zastavíme u jeho nahrazování neohýbaným tvarem substantivním Jak přesně funguje Dr. Klaus Volker objev?... Př́pravek založený na Dr. Klaus Volker objevu odstraňuje hlavní př́činu hypertenze (reportér a V. Ron na internetu 17. 6. 2020).

\section{Závěr}

Pokusili jsme se na př́kladech představit rozvolněnou komunikační praxi, která má dopad nejen na systém apelativ, ale i na systém proprií v kodifikačních příručkách či jiných oficiálních publikacích. Je obtížné stanovit, odkud pohyb vychází, zda jen od apelativ postupuje $\mathrm{k}$ proprím, nebo i naopak, od proprií $\mathrm{k}$ apelativům. Jak jsme naznačili, obě motivace se mohou realizovat. V současnosti je zvláště u proprií zřetelná tendence $\mathrm{k}$ rozvolňování tvarů a $\mathrm{k}$ neohýbání, flexivnost češtiny ustupuje ve prospěch neohebnosti, jistě vlivem západních jazyků, typu angličtiny a francouzštiny, které téměř podoby jmen ne- 
mění. (Proto také západní studenti češtiny nemohou zpočátku pochopit, že podoby Praha, (u) Prahy, a dokonce $(k / v)$ Praze jsou jedním slovem/lexémem).

Otázka je, zda pohyb se děje jen intuitivně, či i záměrně. I na to je obtížná odpověd'. Nepochybně tady přicházejí v úvahu obě možnosti, samozřejmě v závislosti na jednotlivých uživatelích a komunikačních situacích. Ptáme se, zda naznačené tendence budou pokračovat a popř do jaké míry. Budou zasaženy jen některé typy jmen, např. propria, nebo naveskrz celý systém flexe? Viz slovanské jazyky jihovýchodn větve, bulharštinu a makedonštinu, v nichž je tento způsob nakládán se jmény pokročilýs.

\section{Literatura}

Akademická příručka českého jazyka, 2014, eds. M. Pravdová, I. Svobodová, Praha: Academia (2., rozšířené vydání 2019). Online: https://prirucka.ujc.cas.cz.

Č e c ho vá M., 2017a, Paralingvální grafické prostředky. Interpunkční znaménka nejen v syntaktické funkci. In: eadem, Život s češtinou. Praha: Academia, s. $109-117$.

Č e c h o vá M., 2017b, Život s češtinou: Nomen omen: Češka- češtinářka-Čechová, Praha: Academia.

Č e c h o vá M., 2019, Onomastická témata ve studiu bohemistiky. In: Propria a ape lativa - aktuálni otázky. Praha: PedF UK, ÚJČ AV ČR, s. 67-72.

Č e c hov á M. a kol., 2013, Český jazyk pro 3. ročnik středních škol, 2., upravené vydání, Praha: SPN.

Č e c ho vá M., Ol i v a K., 1993, Hrátky s češtinou, Praha: SPN.

J e d li čk a A., H a v rán ek B., 1960, Česká mluvnice, Praha: SPN.

D u fe k O., 2016, O ČEZu, UNESCU a Ikee, „Naše řeč” 99, s. 256-268.

D a n e š F., 1949, Nominativ jmenovací, „Naše řeč” 33, s. 54 -57.

D v o ř á k o v á K., 2015, Jak se pišse wifi, „Naše řeč” 98, s. 220-223.

Ho ffm a n o vá J., Z e m a n J., 2017, Výzkum syntaxe mluvené češtiny: inventarizace problémi̊, „Slovo a slovesnost” 78, s. 45-66.

H a v rá n e k B., J e d li č k a A., 1960, Česká mluvnice, 1. vydání, Praha: SPN.

Jelínek J., Styblík Vl., Čtení o českém jazyku, Praha: Státní pedagogické nakladatelství.

${ }^{3}$ Děkuji Pavlu Štěpánovi za pečlivé pročtení a za doplnění dokladů.
Jíl k o vá L., 2019, Toponyma v dopravním rozhlasovém zpravodajství, „Jazykové aktuality" 56, s. $88-100$

Jíl k o vá L.,2018, K výslovnosti th ve slově smoothie, ,Naše řeč” 101, s. 112-115.

K o lář o vá I., 1999, Jméno obce jako součást názvư územnich celků a institucí, konkurence nominativu jmenovacího a lokálu. In: Propria v systému mluvnickém a slovotvorném, Brno: Pedagogická fakulta Masarykovy univerzity, s. $121-126$.

M i ná ŕ o vá E., T u š k o vá J. M. a kol., 2015, Čeština v pohybu. Kapitoly ke zkoumání jejího stavu a proměn, Brno: MU.

O li v o vá L. a kol., 1995, Pomístní jména v Čechách, Praha: Academia.

P o lív k o vá A., 1985 (2007), Naše mistníjména a jakje uživat, Praha: Academia.

Pravidla českého pravopisu, 1993, Praha: Academia.

S m e j k a lová K., 2019, Rozdíly v deklinaci apelativ a proprií. In: Propria a apelativa - aktuální otázky. Praha: PedF UK, ÚJČ AV ČR, s. 287-294.

S v o b o d o vá I., 2017/2018, Užití nominativu jmenovacího, „Český jazyk a literatura" 68 , s. $37-39$

Š i m a n d 1 J., 2000, Morfologická problematika v jazykové poradně, 1. část, „Naše řeč" 83 , s. $57-76$

Š m il a u e r V., 1966, Novočeská skladba, Praha: SPN.

Š o l c o vá B. P., 2018, Češi ve světě 4, Chorvatsko, Praha: Dům zahraniční spolupráce.

Š rá m e k R., 1999, Úvod do obecné onomastiky, Brno: MU.

Šr áme k R., 1999, Ke gramatickým vlastnostem proprií. In: Propria v systému mluvnickém a slovotvorném, Brno: MÚ, s. 16-23.

Št ěpán P., 2019, Mezi morfologií a slovotvorbou: gramatická kategorie čísla u toponym. In: Propria a apelativa - aktuální otázky. Praha: PedF UK, ÚJČ AV ČR, s. 215-220.

Š tě pá n P., 2020, Psaní velkých pismen u toponym v češtině: polemický pohled. "Acta onomastica” 61, č. 2, s. 417-439.

T u š k o vá J. M., 2016, Onomastická gramatika. In: Nový encyklopedický slovník češtiny, Praha: NLN, s. 1237-1239.

U tě še ný S., 1987, Diskusně k českým místním jménům na -ice, „Onomastický zpravodaj ČSAV" 28, s. 112-120. 